\title{
Evaluation of a new sampling method for assessing Cladocera richness (Crustacea, Branchiopoda) in macrophyte-rich wetlands
}

\author{
Francisco Diogo Rocha Sousa ${ }^{1,2 *}$, Lourdes Maria Abdu Elmoor-Loureiro ${ }^{2}$, \\ Luciana Mendonça-Galvão ${ }^{2}$ and José Roberto Pujol-Luz ${ }^{3}$ \\ 1 Núcleo de Estudos em Biodiversidade Aquática, Programa de Pós-Graduação em Biodiversidade Animal, Universidade Federal de \\ Santa Maria, Avenida Roraima 1000, Camobi, 97105-900 Santa Maria, RS, Brazil \\ 2 Laboratório de Biodiversidade Aquática, Universidade Católica de Brasília, Grupo de Estudos de Ecossistemas Aquáticos, QS 7 , \\ Lote 1, bloco M, salas 204, CEP 71966-700 Taguatinga Sul, DF, Brazil \\ 3 Departamento de Zoologia, Instituto de Ciência Biológicas, Universidade de Brasília, CEP 70910-900 Brasília, DF, Brazil
}

Received 25 June 2013; Accepted 17 February 2014

\begin{abstract}
The wetlands found in the Brazilian Cerrado are poorly studied environments regarding ecological aspects. Assessing the diversity of aquatic invertebrates in wetlands is a challenging task, since there are no standard sampling methods that minimize the spatial effects caused by macrophytes. The aim of this study was to evaluate the efficiency of a new sampling method for assessing Cladocera richness in macrophyte-rich wetlands of Brazilian Cerrado. In six wetlands, one transect was established which corresponded to a gradient of depth or change in aquatic vegetation. Samples containing cladocerans were collected using plankton net dragged among aquatic vegetation in the dry and rainy seasons. The species accumulation curves using non-parametric estimators and the overestimation of richness were used to determine the sampling efficiency. The species accumulation curves showed different asymptotic trends regarding the season and wetland studied. Especially in the rainy season, an asymptotic trend was not observed in two of the wetlands studied, which may reflect the influence of seasonality on Cladocera assemblage. Nevertheless, the overestimation of species richness showed that the method of sampling was able to find more than $60 \%$ of the estimated species richness, regardless of season or wetland studied. These results indicate that the method employed for sampling Cladocera in the Cerrado wetlands can be considered adequate.
\end{abstract}

Key words: Cerrado / microcrustaceans / preserved areas / rainy season / spatial heterogeneity

\section{Introduction}

In the current context of natural environment degradation, recognizing the biodiversity within ecosystems has become an indispensable tool for monitoring and maintenance of ecological processes. Undoubtedly, getting the number of species of a particular plot or ecosystem is the simplest and most widely used measurement to characterize the diversity of ecological assemblages (Magurran, 2004). For practical reasons, for any study of diversity it is almost impossible to record all the species present in an assemblage, because it requires an extensive sampling effort on temporal and spatial scales (Gotelli and Colwell, 2001; Gonzáles-Oreja et al., 2010; Glowacki, 2011).

Currently, several studies about diversity have used and recommended the non-parametric estimators of species richness to minimize the effects of biased sampling

*Corresponding author: sousa_bio@yahoo.com.br on the final results for the number of species (e.g., Petersen et al., 2003; Caterino, 2007; Merlo et al., 2010; Zagmajster et al., 2010). These methods for estimation can be used for comparisons of the analysis of ecological assemblages, since they are obtained through abundance or incidence data (Magurran, 2004); they can also be applied to biotic groups where the number of individuals is difficult to assess, especially in modular organisms, colonies and clones (Williams et al., 2007; Cruz et al., 2008; Gotelli and Colwell, 2010). Another important issue is that, hypothetically, the non-parametric estimators of species richness produce good estimates even for a small set of samples or individuals, and their results can be used as an assessment tool in strategies for species inventories (Magurran and Queiroz, 2010).

The Brazilian tropical savanna, known as Cerrado, is considered a hotspot widely recognized by its high level of endemism (Klink and Machado, 2005). This in turn suggests that wetlands included in this biome could harbor 
a high diversity of species, as shown by Reid (1984, 1987, 1993, 1994) to microcrustaceans of the suborder Copepoda. Their potential contribution to biodiversity puts the wetlands of the Brazilian Cerrado among the priority target areas for conservation. Nevertheless, the presence of any kind of aquatic ecosystem is not a major criterion in the choice of conservation areas, since they are designed through studies of terrestrial flora and fauna. Thus, aquatic biodiversity has not been the focus of conservation strategies, which can lead to a considerable loss of species richness of this region (Agostinho et al., 2005).

According to the Ramsar Convention (information paper No. 1), wetlands that occur on upwelling groundwater or where there are water-saturated soils are categorized as paludal. This type of wetland is widely distributed in the Brazilian Cerrado, and it is considered a heterogeneous ecosystem due to the presence of large numbers of plant species with different life forms and morphological architectures. These characteristics favor the association of a high diversity of taxonomic groups for differential diversification of ecological niches and habitats (Thomaz and Cunha, 2010).

However, knowledge about any ecological aspect of the wetlands of the Brazilian Cerrado is largely neglected. In case of Cladocera, which the most species live in association with aquatic macrophytes (Forró et al., 2008), the information is only preliminary (Elmoor-Loureiro, 2007; Sousa and Elmoor-Loureiro, 2008). These studies presented the species richness; however, there was no attempt to assess the sampling effort because no systematized methods was used for data collection.

Some sampling methods for different groups of microfauna associated with macrophytes, including cladocerans, have been proposed in the literature. Campbell et al. (1982) tested the use of a hand-operated vacuum pump for sampling Cladocera associated exclusively with Chara sp. and Hydrolea ovata. Sakuma et al. (2002) suggested two methods based on sampling of submerged macrophytes using bottles to obtain the phytophilous fauna. Ferreira et al. (2008) used three different methods to sample environments dominated by macrophytes (Jar, Manual Removal and Ekman Dredge) and concluded that the abundance and richness of the biota groups were dependent of the method used. Loutte et al. (2008) used a sampler tube for the collecting cladocerans in dominated macrophytes ponds. Standard methods for sampling zooplankton have also been used (Maia-Barbosa et al., 2008; Kruk et al., 2009). These sampling methods may not be appropriate for particular environments, such as shallow wetlands macrophytes rich, because greater effort would be needed to try to minimize the possible effects of spatial scales, such as depth, architecture and richness of macrophytes (Vieira et al., 2007; Thomaz et al., 2008; Hansen et al., 2011; Lucena-Moya and Duggan, 2011).

Furthermore, other studies reveled the influence of structural complexity provided by macrophytes to small body animals (such as Cladocera). The main feature pointed is the density increasing because of the decline on predation rate in function of the refuge zones provides by aquatic vegetation (Thomaz et al., 2008; Padial et al., 2009; Thomaz and Cunha, 2010; Mormul et al., 2011). This feature, undoubtedly influence the diversity of species and need to be considered in sampling methods that aim survey biodiversity data.

In the past 3 years, research projects on biodiversity of the Cerrado have focused on the standardization of sampling techniques for assessment in aquatic ecosystems in order to generate data that can be used in comparisons of richness and diversity. The aim of this study was to evaluate the efficiency of a new sampling method for assessing Cladocera richness in macrophyte-rich pristine wetlands of Brazilian Cerrado.

\section{Methods}

\section{Study area}

The study was carried out in Central Brazil, in two preserved areas of Cerrado: Brasília's National Park (BNP) and the Formosa's Instructional Camp (FIC) (Fig. 1). The BNP has a total area of 42389 ha, making it the largest Conservation Unit in the Federal District, Brazil. The aquatic ecosystems of BNP belong to the upper Paraná River basin and are represented mainly by headstreams, but several natural wetlands formed by upwelling groundwater are also found. For this study, three paludal wetlands were sampled: Henrique Pond (HE) $\left(15^{\circ} 41^{\prime} 18^{\prime \prime S}, 47^{\circ} 56^{\prime} 10^{\prime \prime} \mathrm{W}\right)$, Exército Pond (EX) (15 44'44.3"S, 47 58'49.1"W) and Peito de Moça (PM) $\left(15^{\circ} 45^{\prime} 05.8^{\prime \prime} \mathrm{S}, 48^{\circ} 01^{\prime} 33.2^{\prime \prime} \mathrm{W}\right)$. These wetlands have many species of macrophytes occupying more than $80 \%$ of the water surface. Examples of species commonly found are: Rhynchospora globosa (Kunth) Roem. \& Schult, Cyperus haspan L. and Cyperus articulatus L. The richness of macrophytes is considered higher, with EX presenting 19 species, HE 26 species and PM 41 species (see Sousa, 2012).

The FIC is located in the state of Goiás and is a training camp for the Brazilian Army. It is bordered to the east by the Federal District and to the south by Minas Gerais state. The FIC is a large preserved fragment of Cerrado and has several types of aquatic ecosystems, such as lotic systems and wetlands, belonging to the upper São Francisco River basin. In this study, we sampled the following natural paludal wetlands: Cabocla I Pond (CBI) $\left(15^{\circ} 48^{\prime} 16.6^{\prime \prime} \mathrm{S}, 47^{\circ} 14^{\prime} 58.8^{\prime \prime} \mathrm{W}\right)$, Cabocla II Pond (CBII) $\left(15^{\circ} 48^{\prime} 22.6^{\prime \prime} \mathrm{S}, 47^{\circ} 14^{\prime} 10.6^{\prime \prime} \mathrm{W}\right)$ and Grande Pond (GR) $\left(15^{\circ} 49^{\prime} 37.3^{\prime \prime} \mathrm{S}, 4713^{\prime} 50.8^{\prime \prime} \mathrm{W}\right)$. These wetlands also have numerous species of macrophyte, for example, Eleocharis capillaceae Kunth, Eleocharis minima Kunth, Scleria hirtella Sw. and C. articulatus L. In the total, CBI presented 44 species of macrophytes, CBII 16 species and GR 22 species (see Sousa, 2012).

The wetlands studied are classified as inland wetlands featuring a relatively stable water level (Source: National Institute of Science and Technology on Wetlands), but they are subject to small fluctuations 


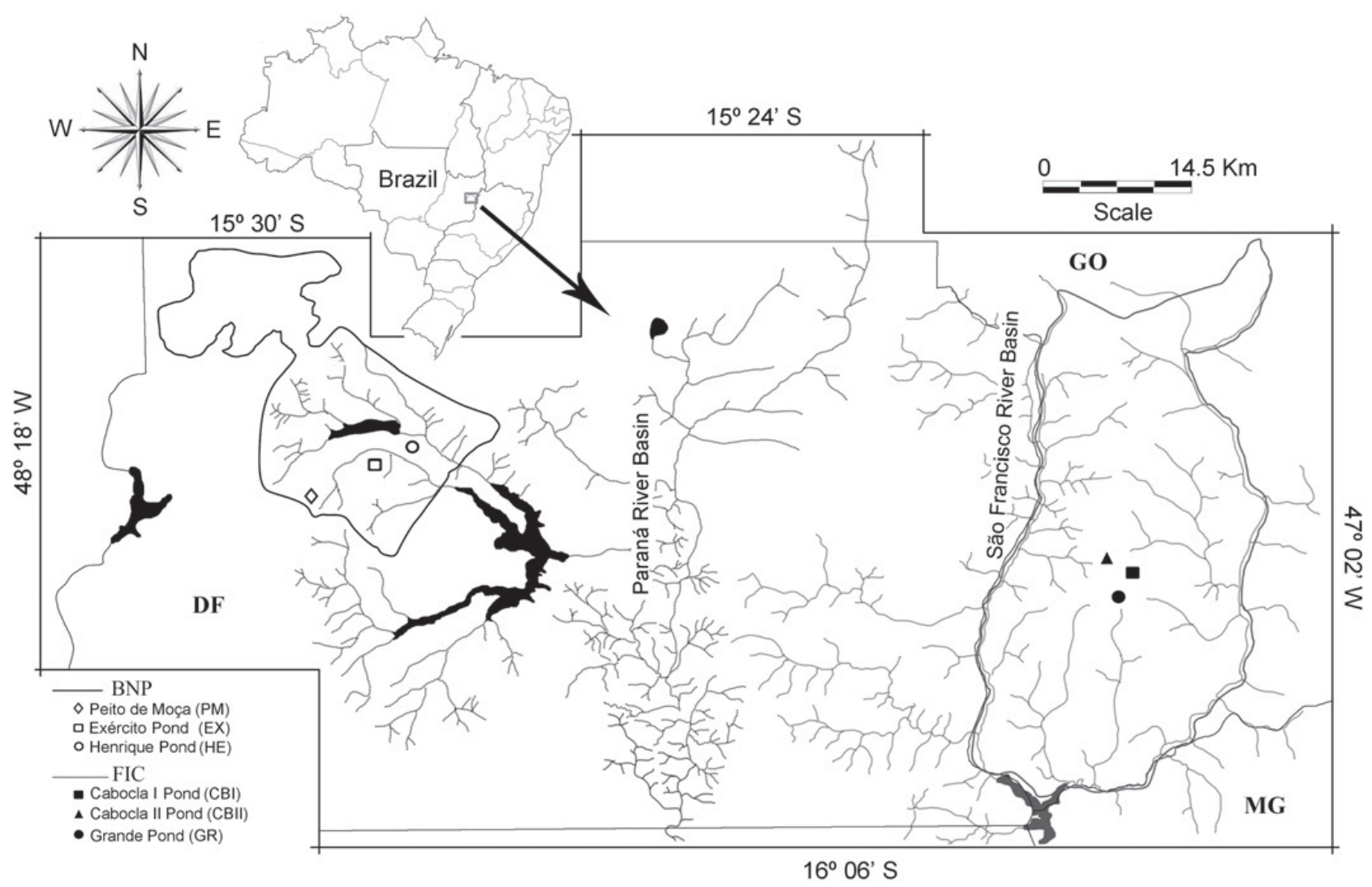

Fig. 1. Location of BNP and FIC, their drainage basins (Paraná and São Francisco) and paludal wetlands studied.

Table 1. Transects parameters in the studied wetlands: number of sampling points, depth average, maximum and minimum length of the transects. BNP - Brasília's National Park and FIC - Formosa's Instructional Camp.

\begin{tabular}{|c|c|c|c|c|c|c|}
\hline \multirow[b]{2}{*}{ Codes } & \multirow[b]{2}{*}{ Wetlands } & \multicolumn{5}{|c|}{ Transects } \\
\hline & & $\begin{array}{c}\text { Number of } \\
\text { sampling points } \\
\text { dry season }\end{array}$ & $\begin{array}{l}\text { Number of } \\
\text { sampling points } \\
\text { rainy season }\end{array}$ & $\begin{array}{l}\text { Depth }(\mathrm{m}) \\
\text { dry season }\end{array}$ & $\begin{array}{l}\text { Depth }(\mathrm{m}) \\
\text { rainy season }\end{array}$ & $\begin{array}{l}\text { Maximum length } \\
(\mathrm{m})\end{array}$ \\
\hline & BNP & & & & & \\
\hline $\mathrm{HE}$ & Henrique Pond & 5 & 5 & $0.58(0.05-1.03)$ & $0.73(0.25-1.20)$ & 46 \\
\hline $\mathrm{EX}$ & Exército Pond & 5 & 5 & $0.19(0.01-0.90)$ & $0.33(0.15-1.00)$ & 50 \\
\hline PM & Peito de Moça & 3 & 3 & $0.05(0.05-0.05)$ & $0.05(0.05-0.05)$ & 50 \\
\hline & FIC & & & & & \\
\hline CBI & Cabocla I Pond & 4 & 4 & $0.32(0.03-0.62)$ & $0.43(0.18-0.71)$ & 50 \\
\hline CBII & Cabocla II Pond & 5 & 5 & $0.50(0.11-0.96)$ & $0.65(0.30-1.14)$ & 50 \\
\hline GR & Grande Pond & 4 & 4 & $0.60(0.26-1.17)$ & $0.83(0.42-1.30)$ & 45 \\
\hline
\end{tabular}

in the water level between seasons. These wetlands are represented by moist grasslands, earth mounds (murundus) and shallow ponds. The wetlands are pristine, oligothrophic and are located in grasslands physiognomies of the Cerrado. No information about the other biota groups for theses environments are available.

The two preserved areas are under typical climatic conditions of the Cerrado domain (Aw, rainy tropical, according to the Köppen classification), marked by strong seasonality. The dry season occur between May and September, presenting lower temperatures. The rainy season (warmer period) from October to April (Sano et al., 2008). The range of temperature for this region was $19-23{ }^{\circ} \mathrm{C}$ and precipitation $4-272 \mathrm{~mm}$, according to the National Institute of Meteorology; historical series between 1961 and 2009 .

\section{Inventory method}

In each wetland, a transect was installed from the lowest depth of water table toward the center of the water body. Sampling points were established by changes in the depth or in macrophyte assemblage (Table 1). Therefore, the distance between sampling points were not fixed. In 


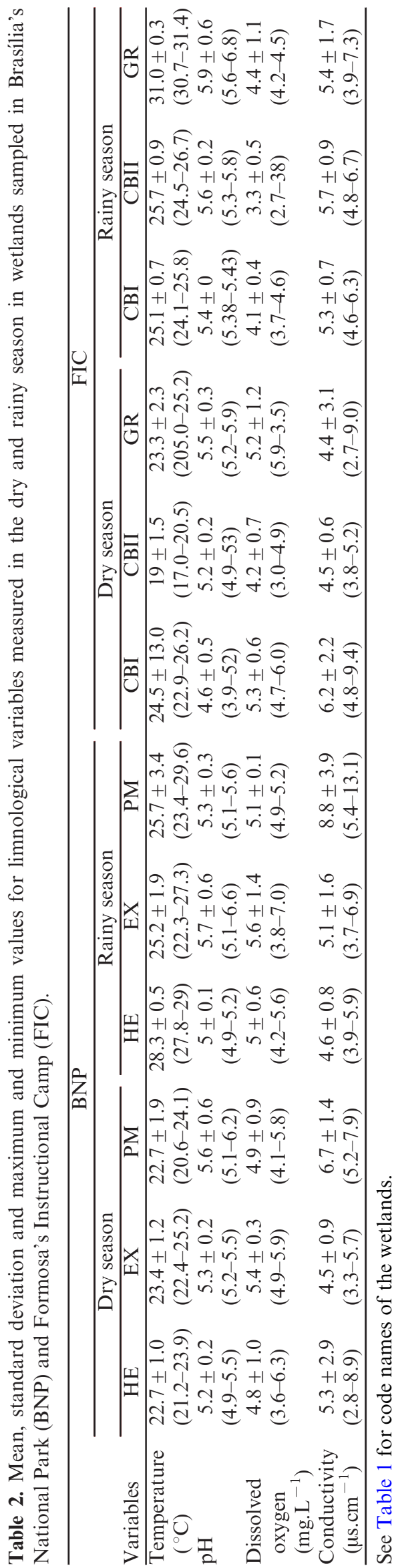

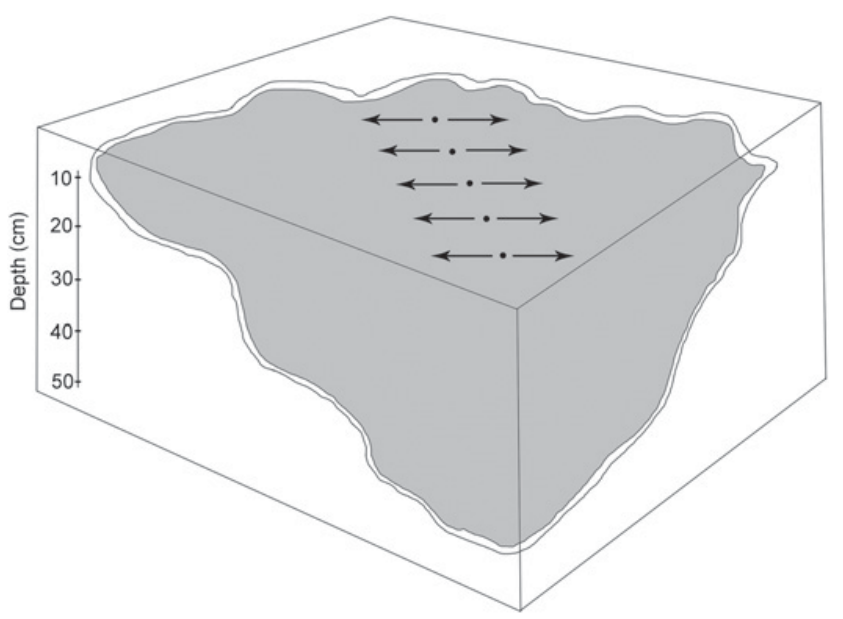

Fig. 2. Schematic diagram showing the formation of transects in each wetland studied. The points refer to the places where the limnological variables were measured and the arrows the range where the samples for Cladocera fauna were taken.

each sampling point, a perpendicular line up to $24 \mathrm{~m}$ was established for data collection (Fig. 2). Depth and some physical and chemical variables of water were measured (Table 2) and Cladocera assemblage was collected.

Samplings were conducted concentrated in the two seasonal periods (dry season, July and August 2009; and rainy season, November and December 2009). The ranges in size of the perpendicular lines to the sampling points were used in order to cover most of the spatial variability in the wetlands.

\section{Collection, sorting and identification of Cladocera}

The fauna was obtained using a plankton net with mesh size of $80 \mu \mathrm{m}$, dragged among the aquatic vegetation four times on the way up to $24 \mathrm{~m}$ at each point of the transect. As the wetlands studied are shallow, dragging net allowed to sample macrophytes with different life forms (rooted emergent plants, rooted submerged plants and floating plants) and structures that they offer for association of invertebrates, as roots, stems, petioles and leaves. Furthermore, the drag was used to capture species swimming in the water among vegetation, such as Daphnidae and some Sididae. The animals were anesthetized in carbonated water, and then fixed in ethanol with final proportion of $70 \%$. At each point within transects, a sample was collected and aliquots with volume of $4 \mathrm{ml}$ were examined under stereomicroscope until stabilization of species richness.

All individuals obtained were identified with the support of taxonomic references (Smirnov, 1992, 1996; Elmoor-Loureiro, 1997; Kotov et al., 2004; Kotov and Štifter, 2006; Sinev and Elmoor-Loureiro, 2010; Van Damme et al., 2010, 2011). The voucher specimens are deposited at the Laboratory of Aquatic Biodiversity of the Catholic University of Brasília. 
Table 3. List of species of Cladocera (Crustacea) found in the studied wetlands in Brasília's National Park (BNP) and Formosa's Instructional Camp (FIC).

\begin{tabular}{|c|c|c|c|c|c|c|c|c|c|c|c|c|}
\hline \multirow[b]{2}{*}{ Taxa } & \multicolumn{6}{|c|}{ Dry season } & \multicolumn{6}{|c|}{ Rainy season } \\
\hline & $\overline{\mathrm{HE}}$ & EX & PM & CBI & CBII & GR & $\overline{\mathrm{HE}}$ & EX & $\mathrm{PM}$ & CBI & CBII & GR \\
\hline Sididae Baird, 1850 & & & & & & & & & & & & \\
\hline Latonopsis australis-group & & & & & • & $\bullet$ & - & & & & $\bullet$ & $\bullet$ \\
\hline Daphniidae Straus, 1829 & & & & & & & & & & & & \\
\hline Ceriodaphnia cornuta (Sars, 1886) & & & & & • & & • & & & & & \\
\hline Ceriodaphnia sp1 & & & & & $\bullet$ & & & & & & $\bullet$ & \\
\hline Ceriodaphnia sp2 & & & & & & & & & & & $\bullet$ & \\
\hline Ilyocryptidae Smirnov, 1992 & & & & & & & & & & & & \\
\hline Ilyocryptus spinifer (Herrick, 1882) & $\bullet$ & $\bullet$ & $\bullet$ & $\bullet$ & $\bullet$ & $\bullet$ & $\bullet$ & $\bullet$ & $\bullet$ & • & $\bullet$ & • \\
\hline Macrothricidae (Norman and Brady, 1867) & & & & & & & & & & & & \\
\hline Macrothrix elegans (Sars, 1901) & & & & & & $\bullet$ & & & & & & $\bullet$ \\
\hline Macrothrix paulensis (Sars, 1900) & $\bullet$ & & & $\bullet$ & $\bullet$ & & $\bullet$ & • & & $\bullet$ & $\bullet$ & $\bullet$ \\
\hline Streblocerus pygmaeus (Sars, 1901) & & • & & & $\bullet$ & & & $\bullet$ & & & $\bullet$ & $\bullet$ \\
\hline Chydoridae Stebbing, 1902 & & & & & & & & & & & & \\
\hline $\begin{array}{l}\text { Acroperus tupinamba Sinev and } \\
\text { Elmoor-Loureiro, } 2010\end{array}$ & & & $\bullet$ & $\bullet$ & & & & & & $\bullet$ & & \\
\hline Alona dentifera (Sars, 1901) & $\bullet$ & & & & $\bullet$ & & & & & & & \\
\hline Alona glabra (Sars, 1901) & & & & & & & & & & & $\bullet$ & \\
\hline Alona iheringula (Sars, 1901) & • & • & $\bullet$ & $\bullet$ & $\bullet$ & $\bullet$ & $\bullet$ & $\bullet$ & & $\bullet$ & $\bullet$ & $\bullet$ \\
\hline Alona intermedia (Sars, 1862) & $\bullet$ & • & & & $\bullet$ & $\bullet$ & & & & & $\bullet$ & - \\
\hline Alona ossiani (Sinev, 1998) & $\bullet$ & $\bullet$ & $\bullet$ & • & • & • & $\bullet$ & $\bullet$ & $\bullet$ & $\bullet$ & $\bullet$ & • \\
\hline Alona setigera $($ Brehm, 1931) & $\bullet$ & • & $\bullet$ & $\bullet$ & & & $\bullet$ & $\bullet$ & & & $\bullet$ & \\
\hline Alona sp. & & & $\bullet$ & & & & & & & & & \\
\hline Alonella clathratula (Sars, 1896) & $\bullet$ & $\bullet$ & & $\bullet$ & • & $\bullet$ & $\bullet$ & $\bullet$ & & $\bullet$ & $\bullet$ & - \\
\hline Alonella dadayi (Birge, 1910) & $\bullet$ & $\bullet$ & & $\bullet$ & $\bullet$ & & $\bullet$ & $\bullet$ & & $\bullet$ & $\bullet$ & $\bullet$ \\
\hline Anthalona verrucosa (Sars, 1901) & $\bullet$ & & & $\bullet$ & & $\bullet$ & $\bullet$ & • & & $\bullet$ & $\bullet$ & - \\
\hline $\begin{array}{l}\text { Celsinotum candango Sinev and } \\
\text { Elmoor-Loureiro, } 2010\end{array}$ & $\bullet$ & & & & & & $\bullet$ & $\bullet$ & & & & \\
\hline Chydorus dentifer (Daday, 1905) & & & & • & & $\bullet$ & & & & & & - \\
\hline Chydorus eurynotus (Sars, 1901) & & & & • & $\bullet$ & $\bullet$ & $\bullet$ & $\bullet$ & & - & $\bullet$ & - \\
\hline Chydorus pubescens (Sars, 1901) & $\bullet$ & & & & & $\bullet$ & $\bullet$ & & & & $\bullet$ & $\bullet$ \\
\hline Disparalona leptorhyncha Smirnov, 1996 & & & & & & $\bullet$ & & & & & & $\bullet$ \\
\hline Dunnhevedia odontoplax (Sars, 1901) & & & & $\bullet$ & & & & & & & & \\
\hline Ephemeroporus sp. & $\bullet$ & & & & • & $\bullet$ & • & $\bullet$ & & & • & • \\
\hline Ephemeroporus barroisi (Richard, 1984) & $\bullet$ & $\bullet$ & & $\bullet$ & $\bullet$ & $\bullet$ & $\bullet$ & $\bullet$ & & $\bullet$ & $\bullet$ & $\bullet$ \\
\hline Graptoleberis occidentalis (Sars, 1901) & $\bullet$ & $\bullet$ & & - & • & $\bullet$ & - & & & $\bullet$ & $\bullet$ & $\bullet$ \\
\hline Karualona muelleri (Richard, 1897) & $\bullet$ & & & & & $\bullet$ & & $\bullet$ & & & & $\bullet$ \\
\hline Leydigiopsis curvirostris (Sars, 1901) & • & & & & & & • & & & & $\bullet$ & \\
\hline Notoalona sculpta (Sars, 1901) & $\bullet$ & & & & & & & & & & & \\
\hline
\end{tabular}

See Table 1 for code names of the wetlands.

\section{Data analyses}

The number of species observed in each wetland was compared in the dry season and rainy season using oneway ANOVA - followed by Tukey test. These analyses were performed using the software PAST (Hammer et al., 2001). In order to avoid violations the of normality and homoscedasticity assumptions, data were transformed using $\log (x+1)$.

Individual-based non-parametric estimators of species richness (ACE, Chaol and first-order Jackknife) were calculated to assess the total richness in each wetland using EstimateS 8.2 (Colwell, 2009). In general, these estimators perform an approximation of total richness through comparisons between rare species (singletons) and species shared between at least two samples (doubletons). In this study, singletons species with less than ten individuals and doubletons species with less than ten individual shared between two samples were considered. The formulas for the calculation of the estimators are found in Gotelli and Colwell (2010).

Individual-based rarefactions were generated to accumulate the number of species for each wetland (Gotelli and Colwell, 2001). The individual-based rarefaction method was used to reduce possible effects of sampling. To assess whether the number of species was close to the total expected for the wetlands, species accumulation curves were constructed and trends to asymptote were analyzed (Colwell and Coddington, 1994; Gotelli and Colwell, 2010).

\section{Results}

A total of 31 species were observed, belonging to five families (Table 3). In the BNP, difference in mean richness 

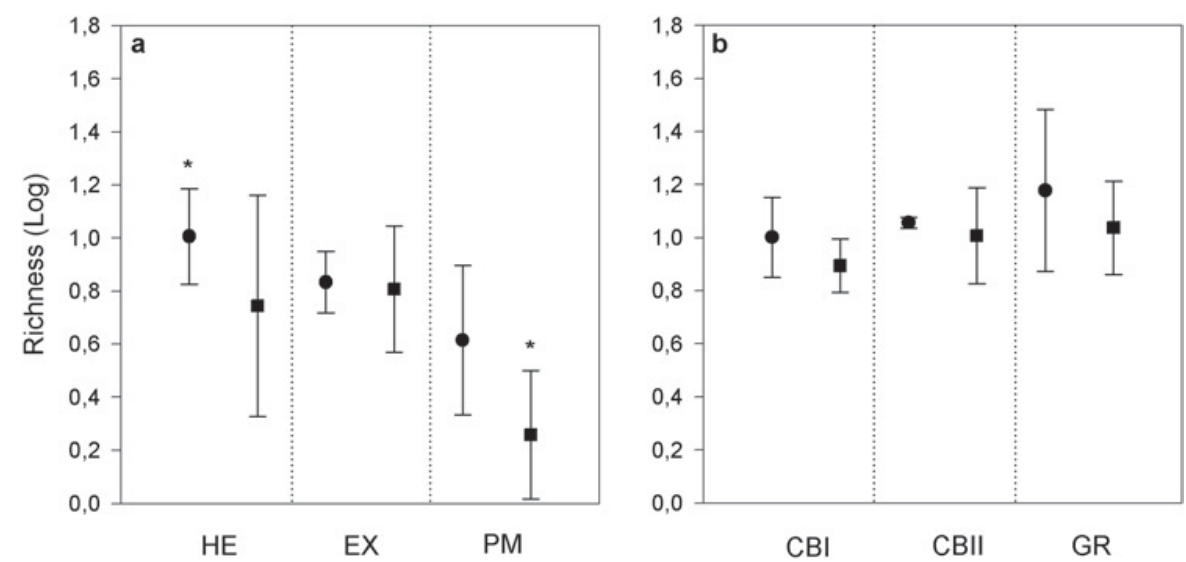

Fig. 3. Log of the mean and standard error of the number of species observed in the studied wetlands. (a) Wetlands of BNP and (b) wetlands of FIC. HE - Henrique pond; EX - Exército pond; PM - Peito de moça; CBI - Cabocla I pond; CBII - Cabocla II pond and GR - Grande pond. Dots - dry season; square - rainy season *significant difference in species richness $P<0.05$.

between HE and PM was observed between dry and rainy seasons $(F=3.642 ; P=0.0287$; Tukey test: $P=0.01)$ (Fig. 3(a)). The trend of the species accumulation curves for the estimators was not similar between wetlands of the BNP. For example, in HE both estimators in the dry season reached the asymptote at just over 100 individuals sampled, where the curves of singletons and doubletons visibly declined with an increase in the number of individuals (Fig. 4(a)).

In EX, it was possible to observe the formation of the asymptote in the dry season at approximately 100 individuals, but, as the curve of singletons increased, the species accumulation curves corresponding to the estimators did not reach an asymptote and visibly tended to increase (Fig. 4(c)). In the rainy season, only Jackk1 approached asymptotic behavior (Fig. 4(d)). However, in the PM, Jackk1 was the only estimator to show asymptotic behavior in the dry season (Fig. 4(e)). Accumulation of species curves was not performed in the rainy season for PM because only 11 individuals were found for the set samples, while the presence of at least 20 individuals is recommended for the construction of these curves (Gotelli and Colwell, 2010).

In the wetlands of the FIC, there was no difference in mean richness observed (Fig. 3(b)) $(F=1.27 ; P=0.378)$. In CBI, it was observed that the species accumulation curves reached asymptote at just over 200 individuals in the dry season (Fig. 5(a)). In the rainy season, asymptote was observed for all curves (Fig. 5(b)). In the dry season, CBII reached asymptote, and the singleton and doubleton curves showed differences, with an increasing tendency for singletons and visibly declining after 300 individuals for doubletons (Fig. 5(c)). In the rainy season, only the accumulation curve for Jackk1 reached asymptote, probably influenced by doubletons, which decreased (Fig. 5(d)).

Still for the FIC, the wetland named GR obtained asymptote only in the species accumulation curves for Jackk1, and singletons and doubletons declined after 250 individuals (Fig. 5(e)). In the rainy season, none of the richness estimators reached asymptote (Fig. 5(f)).
The application of estimators for the studied wetlands predicted that, depending on the area, on the dry and rainy seasons and the estimator used, between 5 and $35 \%$ of species estimated for the studied areas were not accessed (Table 4-6). This means that it was possible to access a sufficient number of species for wetlands studies here. According to Heck et al. (1975), a survey of species could be considered satisfactory when are obtained between 50 and $70 \%$ of species that potentially occur in a plot or ecosystem.

\section{Discussion}

Studies of wetlands have been conducted in Brazil on large floodplains, such as the Paraná River floodplain and the Pantanal (e.g., Roberto et al., 2009; Alho, 2011). These two large Brazilian wetlands have extremely rich Cladocera fauna, with estimates ranging between 60 and 85 species (Hollwedel et al., 2003; Serafim-Júnior et al., 2003; Junk et al., 2006). However, it would be wrong to compare richness obtained in this study to the results of large wetlands, due to differences in spatial and temporal scales, since these large wetlands have been the focus of studies for over 20 years.

Also evaluating shallow wetlands that were densely covered by macrophytes in the Paranã River basin, Goiás state, Elmoor-Loureiro (2007) reported richness values between 4 and 19. In another study in shallow wetlands in the Brazilian Cerrado, Sousa and Elmoor-Loureiro (2008) found 11 species in the richest site and four in the poorest site in an inventory of Cladocera fauna conducted in the Emas National Park, also in Goiás state. Their results are quite similar to the ones reported by this study the BNP and FIC (Tables 4 and 5), and it is noticeable that the number of species is very similar. However, the lack of standardization in the sampling does not allow making comparisons with results found in Elmoor-Loureiro (2007) and Sousa and Elmoor-Loureiro (2008). 

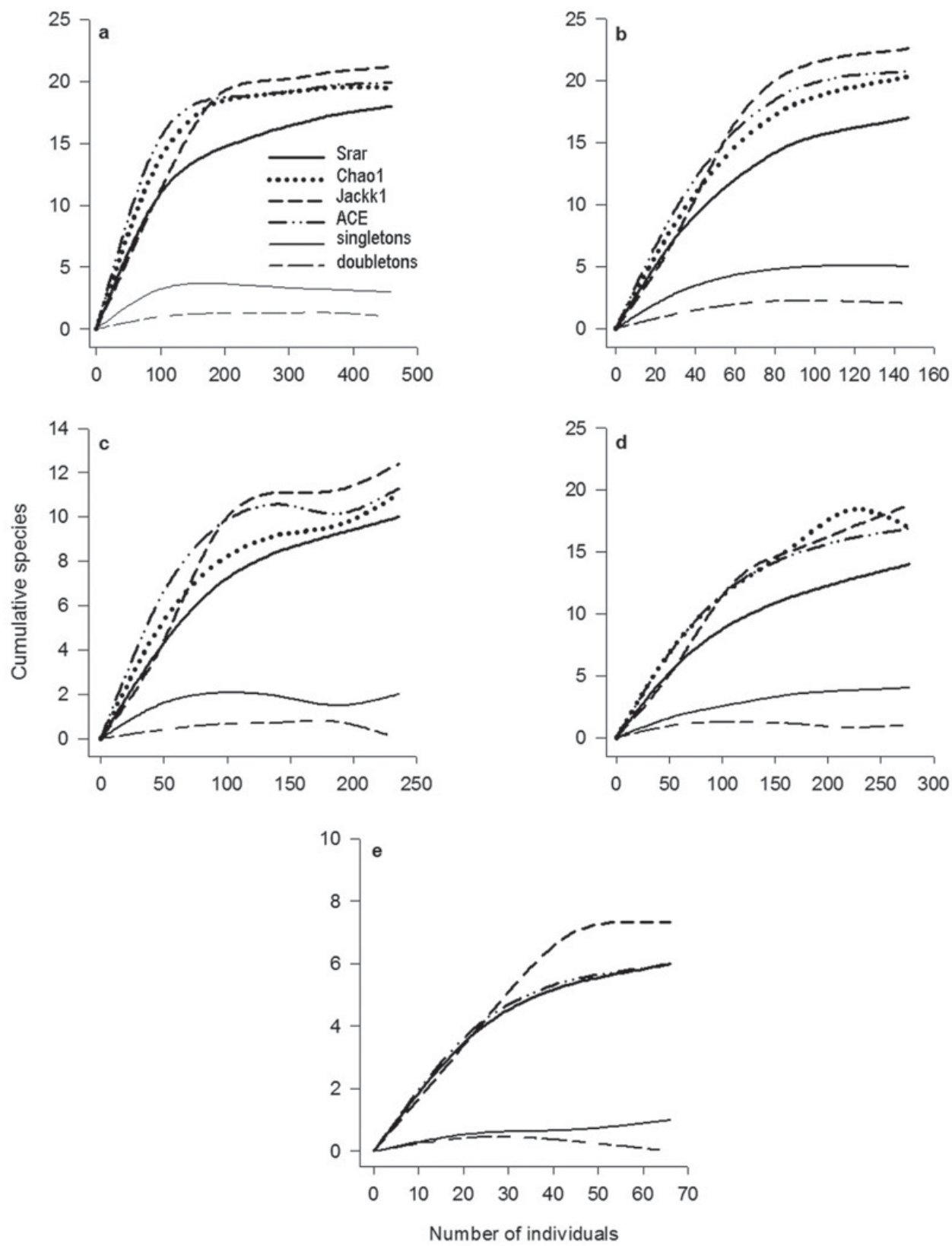

Fig. 4. Species accumulation curves for wetlands in BNP. (a) HE dry season, (b) HE rainy season, (c) EX dry season, (d) EX rainy season and (e) PM dry season.

Non-parametric estimators have been used to assess the richness of aquatic invertebrates, and the results are always given by overestimation of observed richness (Melo and Froehlich, 2001; Muirhead et al., 2006; Turki and Turki, 2010), but the asymptotic trends of species accumulation curves for these estimators can indicate whether results are representative. We observed the asymptote of the species accumulation curves for the estimators in wetlands studied here (Figs. 4 and 5). The trend of the species accumulation curves for estimators is a function of the numbers of rare species (Melo, 2004). In all areas where curves reached asymptote at least for one estimator, it is possible to observe a decrease, or at least a stabilization of the curves of rare species (singletons and doubletons), indicating that the likelihood of new species being added is low, when sampling effort is increased (Melo, 2004).

The use of non-parametric estimators can also reveal failures in the methods of sampling, as some studies have already indicated (Muirhead et al., 2006; Cardoso et al., 2009; Zagmajster et al., 2010) and as noted in the dry season for EX and in the rainy season for GR and CBII because of the non-formation of asymptote of species in accumulation curves. Specifically for wetlands, spatial heterogeneity seems to be an important factor that can lead to failures in sampling (Kaeser and Kirkman, 2009). For the wetlands studied here, a factor of heterogeneity are the macrophytes, which are responsible for increasing 

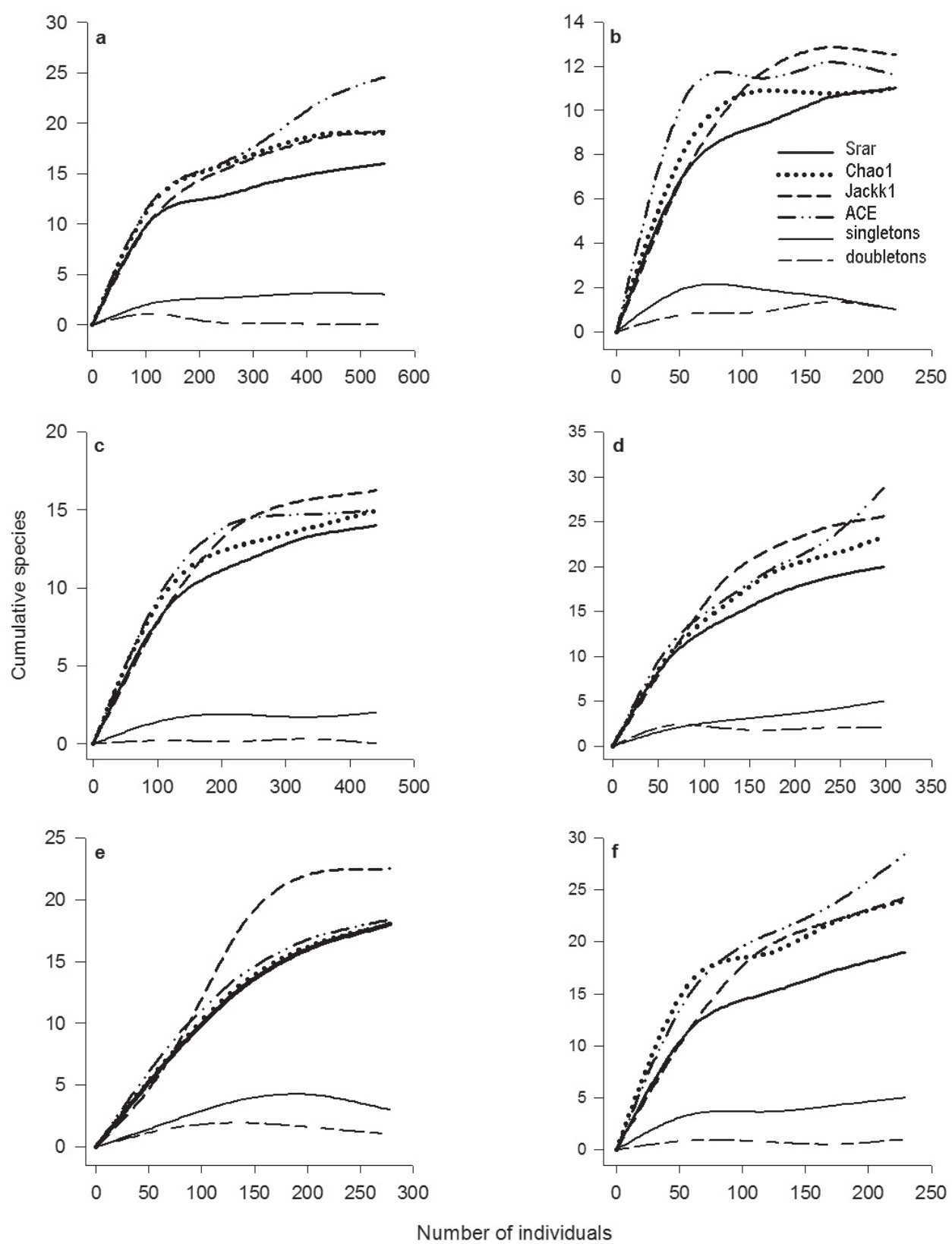

Fig. 5. Species accumulation curves for wetlands in the FIC. (a) CBI pond dry season, (b) CBI pond rainy season, (c) CBII pond dry season, (d) CBII pond rainy season, (e) GR pond dry season and (f) GR pond rainy season.

the spatial variability in aquatic environments, due to their high number of species, life forms and architecture (see Sousa, 2012). It is possible that we did not assess some aspect from the complexity provided by aquatic vegetation in the sampling method used.

Another important factor is the seasonal climate which is, admittedly, characteristic of the Cerrado biome and influences the biological assemblages (Ledru, 2002). Fluctuations in water level are responsible for driving successional process of vegetation in response to seasonality (Middleton, 2002; Odland and Moral, 2002). Fluctuations of small magnitude (lateral expansion of wetland and small changes in water level in the rainy season) are related to increased abundance of vegetation and formation of zones in different stages of succession (van der Valk, 2006; Moore, 2007). As the structure of invertebrates assemblages is linked to changes in vegetation, we considered that fluctuation in the depth, as well as the lateral expansion of the surface water, may favor the development of new species of macrophytes (van der Valk, 2006), expanding also the area of their colonization and, then, increasing the spatial variability in the rainy season.

Furthermore, the dilutive effect of water on the assemblage in the rainy season requires an increase in sampling effort in order to expand the number of collected species, because this probably affects the dispersion. The effect of the rainy season on sampling can be found in 
Table 4. Species richness in wetlands sampled in Brasília's National Park (BNP), Federal District.

\begin{tabular}{|c|c|c|c|c|c|c|}
\hline & \multicolumn{6}{|c|}{$\overline{B N P}$} \\
\hline & \multicolumn{3}{|c|}{ Dry season } & \multicolumn{3}{|c|}{ Rainy season } \\
\hline & $\mathrm{HE}$ & EX & $\overline{\mathrm{PM}}$ & $\mathrm{HE}$ & EX & $\overline{\mathrm{PM}}$ \\
\hline Samples & 5 & 5 & 3 & 5 & 5 & 3 \\
\hline Individuals & 459 & 263 & 66 & 147 & 277 & 11 \\
\hline Srar & $18( \pm 1.27)$ & $10( \pm 1.63)$ & $6( \pm 0.64)$ & $17( \pm 1.78)$ & $14( \pm 2.18)$ & $2( \pm 0.53)$ \\
\hline Singletons & 3 & 2 & 0 & 5 & 4 & - \\
\hline Doubletons & 1 & 0 & 1 & 2 & 1 & - \\
\hline Chaol & $19.50( \pm 2.60)$ & $11( \pm 2.27)$ & $6( \pm 0.01)$ & $22.60( \pm 3.49)$ & $17( \pm 4.18)$ & - \\
\hline Jackk1 & $21.20( \pm 1.96)$ & $12.40( \pm 1.60)$ & $7.33( \pm 1.33)$ & $20.33( \pm 4.13)$ & $18.80( \pm 3.88)$ & - \\
\hline $\mathrm{ACE}$ & 19.91 & 11.27 & 6 & 20.77 & 16.88 & - \\
\hline
\end{tabular}

See Table 1 for code names of the wetlands. Srar - rarefied richness; Jackk1 - first-order Jackknife.

Table 5. Species richness in wetlands sampled in the Formosa's Instructional Camp (FIC), Goiás.

\begin{tabular}{|c|c|c|c|c|c|c|}
\hline & \multicolumn{6}{|c|}{ FIC } \\
\hline & \multicolumn{3}{|c|}{ Dry season } & \multicolumn{3}{|c|}{ Rainy season } \\
\hline & CBI & CBII & GR & CBI & CBII & GR \\
\hline$\overline{\text { Samples }}$ & 4 & 5 & 4 & 4 & 5 & 4 \\
\hline Individuals & 441 & 544 & 278 & 222 & 298 & 229 \\
\hline Srar & $14( \pm 1.02)$ & $16( \pm 1.37)$ & $18( \pm 1.24)$ & $11( \pm 0.60)$ & $20( \pm 1.98)$ & $19( \pm 1.92)$ \\
\hline Singletons & 2 & 3 & 1 & 1 & 5 & 5 \\
\hline Doubletons & 0 & 0 & 3 & 1 & 2 & 1 \\
\hline Chaol & $15( \pm 2.29)$ & $19( \pm 4.55)$ & $18( \pm 0.53)$ & $11( \pm 0.25)$ & $23.30( \pm 4.13)$ & $24( \pm 6.05)$ \\
\hline Jackk1 & $16.25( \pm 1.44)$ & $19.20( \pm 1.50)$ & $22.50( \pm 1.50)$ & $12.50( \pm 0.87)$ & $25.60( \pm 2.04)$ & $24.25( \pm 2.56)$ \\
\hline $\mathrm{ACE}$ & 15 & 24.57 & 18.39 & 11.60 & 28.75 & 28.40 \\
\hline
\end{tabular}

See Table 1 for code names of the wetlands. Srar - rarefied richness; Jackk1 - first-order Jackknife.

Table 6. Mean percentage and standard deviation of overestimation for each estimator in the studied wetlands in the Cerrado of Central Brazil.

\begin{tabular}{|c|c|c|c|c|c|c|}
\hline & \multicolumn{6}{|c|}{ Mean $\%$ overestimation } \\
\hline & \multicolumn{3}{|c|}{ Dry season } & \multicolumn{3}{|c|}{ Rainy season } \\
\hline & Chaol & Jackk1 & $\mathrm{ACE}$ & Chaol & Jackk1 & $\mathrm{ACE}$ \\
\hline$\overline{\mathrm{HE}}$ & $7.69( \pm 0.19)$ & $15.09( \pm 0.29)$ & 9.60 & $24.77( \pm 0.52)$ & $16.37( \pm 0.67)$ & 18.15 \\
\hline EX & $9.09( \pm 0.20)$ & $19.35( \pm 0.30)$ & 11.26 & $17.65( \pm 0.73)$ & $25.53( \pm 0.99)$ & 17.06 \\
\hline PM & 0 & $18.14( \pm 0.24)$ & 0 & - & - & - \\
\hline CBI & $6.66( \pm 0.15)$ & $13.84( \pm 0.19)$ & 6.66 & 0 & $12( \pm 0.10)$ & 5.17 \\
\hline CBII & $15.78( \pm 0.71)$ & $16.66( \pm 0.24)$ & 34.87 & $14.96( \pm 0.61)$ & $21.87( \pm 0.44)$ & 30.43 \\
\hline GR & 0 & $20( \pm 0.30)$ & 0 & $20.83( \pm 1.26)$ & $21.64( \pm 0.55)$ & 33.09 \\
\hline
\end{tabular}

See Table 1 for code names of the wetlands. Srar - rarefied richness; Jackk1 - first-order Jackknife.

Table 6, where the percentage of richness overestimated was higher than in the dry season in most wetlands. Thus, we can indicate that seasonality is quite relevant to assessing the species richness of Cladocera in wetlands.

In conclusion, all results achieved showed efficiency in obtaining a good set of data using the sampling method described here, since that percentage of overestimation of richness showed that the sampling was adequate. This result can be related to two main features that reduced the effects of spatial variability found in the wetlands studied: (1) sampling in depth gradients and (2) sampling in different substrates involved with Cladocera association (macrophytes with complexity and life forms different). Although observed efficiency in the sampling method, the absence of asymptote in some species accumulation curves indicates the need for increased sampling effort, possibly as a consequence of spatial heterogeneity and seasonality. This can be minimized by increasing the length of transects, increasing the number of sampling points per transect, as well as increasing the distance traveled to drag the plankton net and obtain fauna. These procedures may be necessary during the rainy season, when there is an increase in spatial variability.

There are no standardized methods for collection of data in studies of microcrustacean fauna in wetlands, and different sampling techniques have been used (see Campbell et al., 1982; Sakuma et al., 2002; Ferreira et al., 2008; Loutte et al., 2008; Maia-Barbosa et al., 2008; Kruk et al., 2009). The usage of the same sampling method is an important strategy, since the lack of standardization in 
data collection limits comparisons in studies of biodiversity. Although, developed for assessment of the Cladocera fauna in shallow wetlands, the sampling method proposed and evaluated in this study has great potential for assessing the richness of other groups of aquatic biota as Copepoda, Rotifera and Amoeba Testacea. The sampling method can be tested in ecosystem presenting higher cover aquatic vegetation, such as temporary ponds, littoral zone in reservoirs, lakes and shallow lakes.

Acknowledgements. We are grateful to colleagues from Grupo de Estudos de Ecossistemas Aquáticos (GEEA) involved in field and laboratory works in particular to Elisa Alvim and Bárbara Medeiros Fonseca. We are grateful to Dr Ludgero Cardoso Galli Vieira, Dr Maria José dos Santos-Wisniewski, Dr Bárbara Medeiros Fonseca and Diego Martins Magalhães (MSc.) for the comments. This work received financial support from the Consellho Nacional de Desenvolvimento Científico e Tecnológico $(\mathrm{CNPq})$ through a grant to the first author during his Master degree in the Post-Graduate Ecology Program of the University of Brasília (UnB) and from Federal District Research Foundation (FAP-DF).

\section{References}

Agostinho A.A., Thomaz S.M. and Gomes L.C., 2005. Conservation of the biodiversity of Brazil's inlands waters. Conserv. Biol., 19, 646-652.

Alho C.J.R., 2011. Biodiversity of the Pantanal: its magnitude, human occupation, environmental threats and challenges for conservation. Braz. J. Biol., 71, 229-232.

Campbell J.M., Clark, W.J. and Kosinski, R., 1982. A technique for examination microspatial distribution of Cladocera associated with shallow water macrophytes. Hydrobiologia, 97, 225-232.

Cardoso M.S., Henriques S.S., Gaspar C., Crespo L.C., Carvalho R., Schimdt J.B., Sousa P. and Szus T., 2009. Species richness and composition assessment of spiders in a Mediterranean scrubland. J. Insect Conserv., 13, 45-55.

Caterino M.S., 2007. Species and complementarity of beetle faunas in a mediterranean-type biodiversity hotspot. Biodivers. Conserv., 16, 3993-4007.

Colwell R.K., 2009. EstimateS: Statistical Estimation of Species Richness and Shared Species from Samples. Version 8.2 User's Guide and application published at: http://viceroy.eeb. uconn.edu/EstimateS.

Colwell R.K. and Coddington, J.A., 1994. Estimate terrestrial biodiversity through extrapolation. Phil. Trans. R. Soc. B, 345, 101-118.

Cruz I.C.S., Kikuchi R.K.P. and Leão Z.M.A.N., 2008. Use of the video transect method for characterizing the Itacolomis reefs, eastern Brazil. Braz. J. Oceanogr., 56, 271-280.

Elmoor-Loureiro L.M.A., 1997. Manual de identificação de cladóceros límnicos do Brasil, Universa, Brasília, 156 p.

Elmoor-Loureiro L.M.A., 2007. Phytophilous cladocerans (Crustacea, Anomopoda and Ctenopoda) from Paranã River valley, Goiás, Brazil. Zoologia, 24, 344-352.

Ferreira H.L.M., Souza M.B.G. and Lopez C.M., 2008. Evaluation of sampling methods for periphytic fauna in macrophytes at the Espinhaço mountain range biosphere reserve, Minas Gerais State, Brazil. Acta Sci. Biol. Sci., 30, 253-259.

Forró L., Korovichinsky N.M., Kotov A.A. and Petrusek A., 2008. Global diversity of cladocerans (Cladocera; Crustacea) in freshwater. Hydrobiologia, 595, 177-184.

Glowacki L., 2011. Accuracy of species richness estimator applied to fish in small and large temperate low land rivers. Biodivers. Conserv., 20, 1365-1384.

Gonzáles-Oreja J.A., Garbisu C., Mendarte S., Ibarra A. and Albizu I., 2010. Assessing the performance of non-parametric estimators of species in meadows. Biodivers. Conserv., 19, 1417-1436.

Gotelli N.J. and Colwell, R.K., 2001. Quantifying biodiversity: procedures and pitfalls in the measuring and comparison of species richness. Ecol. Lett., 4, 379-391.

Gotelli N.J. and Colwell R.K., 2010. Estimating species richness. In: Magurran A.E. and McGill B.J. (eds.), Biological Diversity: Frontiers in Measurement and Assessment, Oxford, UK, 39-54.

Hammer Ø., Harper D.A.T. and Ryan P.D., 2001. Past: paleontological statistics software package for education and data analysis. Palaeontol. Electron., 4, 1-9.

Hansen J.P., Wikstrom S.A., Axemar H. and Kautsky L., 2011. Distribution differences and active habitat choices of invertebrates between macrophytes of different morphological complexity. Aquat. Ecol., 45, 11-22.

Heck K.L.J., van Belle G. and Simberloff D., 1975. Explicit calculation of the rarefaction diversity measurement and the determination of sufficient sample size. Ecology, 56, 1459-1461.

Hollwedel W., Kotov A.A. and Brandorff G.O., 2003. Cladocera (Crustacea: Branchiopoda) from the Pantanal (Brazil). Arthropod. Sel., 12, 67-93.

Junk W., Cunha C.N., Wantzen K.M., Peterman P., Strussmann C., Marques M.I. and Adis J., 2006. Biodiversity and its conservation in the Pantanal of Mato Grosso, Brazil. Aquat. Sci., 68, 278-309.

Kaeser J.M. and Kirkman L.K., 2009. Estimating total plant species richness in depressional wetlands in the long leaf pine ecosystem. Wetlands, 29, 866-874.

Klink C.A. and Machado R.B., 2005. A conservação do Cerrado brasileiro. Megadiversidade, 1, 148-155.

Kotov A.A. and Štifter P., 2006. Cladocera: Family Ilyocryptidae (Branchiopoda: Cladocera: Anomopoda), Backhuys Publisher/Kenobi Productions, Leiden/Ghent, 172 p.

Kotov A.A., Garfias-Espejo T. and Elías-Gutiérrez M., 2004. Separation of two Neotropical species: Macrothrix superaculeata (Smirnov, 1982) versus M. elegans Sars, 1901 (Macrothricidae, Anomopoda, Cladocera). Hydrobiologia, 517, 61-88.

Kruk C., Rodríguez-Galego L., Meerhoff M., Quintans F., Lacerot G., Mazeo N., Scasso F., Paggi J.C., Peeters E.T.H.M. and Marten S., 2009. Determinants of biodiversity in subtropical shallow lakes (Atlantic coast, Uruguay). Freshw. Biol., 54, 2628-2641.

Ledru M.P., 2002. Late quaternary history and evolution of Cerrados as revealed by palynological records. In: Oliveira P.S. and Marquis R.J. (eds.), The Cerrados of Brazil, New York, NY, USA, 33-50.

Loutte G., Meester L.D. and Declerck, S., 2008. Assembly of zooplankton communities in newly created ponds. Freshw. Biol., 53, 2309-2320. 
Lucena-Moya P. and Duggan I.C., 2011. Macrophyte architecture affects the abundance and diversity of littoral microfauna. Aquat. Ecol., 45, 279-287.

Magurran A.E. and Queiroz H., 2010. Evaluating tropical biodiversity: do we need a more refined approach? Biotropica, 42, 537-539.

Maia-Barbosa P., Peixoto R.S. and Guimarães A.S., 2008. Zooplankton in littoral waters of a tropical lake: a revisited biodiversity. Braz. J. Biol., 68, 1069-1078.

Melo A.S., 2004. A critique of the use of Jackknife and related non-parametric techniques to estimate species richness. Commun. Ecol., 5, 149-157.

Melo A.S. and Froehlich C.G., 2001. Evaluation of methods for estimating macroinvertebrate species richness using individual stones in tropical streams. Freshw. Biol., 46, 711-721.

Merlo M.J., Parietti M. and Etchegoin J.A., 2010. Evaluation of species richness estimators in studies of diversity involving two larval digenean communities parasitizing snail hosts. Parasitol. Res., 107, 1093-1102.

Middleton B., 2002. Succession and herbivory in monsoonal wetlands. Wetl. Ecol. Manage., 6, 189-202.

Moore P.D., 2007. Wetlands, Revised edn.,, Infobase Publishing, USA, $255 \mathrm{p}$.

Mormul R.P., Thomaz S.M., Takeda A.M. and Behrend R.D., 2011. Structural complexity and distance from source habitat determine invertebrate abundance and diversity. Biotropica, 43, 738-745.

Muirhead J.R., Ejmont-Karabin J. and MacIsaac H.J., 2006. Quantifying rotifer species richness in temperate lakes. Freshw. Biol., 51, 1696-1709.

Odland A. and del Moral R., 2002. Thirteen years of wetland vegetation succession following a permanent drawdown, Myrkdalen lake, Norway. Plant Ecol., 162, 185-198.

Padial A.A., Thomaz S.M. and Agostinho A.A., 2009. Effects of structural heterogeneity provided by the floating macrophyte Eichhornia azurea on the predation efficiency and habitat use of the small Neotropical fish Moenkhausia sanctaefilomenae. Hydrobiologia, 624, 161-170.

Petersen F.T., Meier R. and Larsen M.N., 2003. Testing richness species estimation methods using museum label data on the Danish Asilidae. Biodivers. Conserv., 12, 687-701.

Ramsar information paper no. 1. What are wetlands? Accessed online 26 May 2011, available via DIALOG: www.ramsar.org/about/info2007-01-e.pdf.

Reid J.W., 1984. Semiterrestrial meiofauna inhabiting a wet campo in central Brazil, with special reference to the Copepoda (Crustacea). Hydrobiologia, 118, 95-111.

Reid J.W., 1987. The cyclopoid copepods of a wet campo marsh in central Brazil. Hydrobiologia, 153, 121-138.

Reid J.W., 1993. The Harpacticoid and cyclopoid copepod fauna in the cerrado region of central Brazil. 1. Species composition, habitats, and zoogeography. Acta Limnol. Bras., 6, 56-68.

Reid J.W., 1994. Murunducaris juneae, new genus, new species (Copepoda: Harpacticoida: Parastenocarididae) from a wet campo in central Brazil. J. Crustacean Biol., 14, 771-781.

Roberto M.C., Santana F.C. and Thomaz S.M., 2009. Limnology in the Upper Paraná River floodplain: large-scale spatial and temporal patterns, and the influence of reservoirs. Braz. J. Biol., 69, 717-725.

Sakuma M., Hanazato T., Nakazato R. and Haga H., 2002. Method for quantitative sampling of epiphytic microinvertebrates in lake vegetation. Lymnology, 13, 115-119.

Serafim-Júnior M., Lansac-Tôah F.A., Paggi J.C., Velho L.F.M. and Robertson B., 2003. Cladocera fauna composition in a river-lagoon system of the Upper Paraná River floodplain, with a new record for Brazil. Braz. J. Biol., 63, 349-356.

Sinev A.Y. and Elmoor-Loureiro L.M.A., 2010. Three new species of chydorid cladocerans of subfamily Aloninae (Branchipoda: Anomopoda: Chydoridae) from Brazil. Zootaxa, 2390, 1-25.

Smirnov N.N., 1992. The Macrothricidae of the World, SPB Academic Publishing, Amsterdam, 143 p.

Smirnov N.N., 1996. Cladocera: The Chydorinae and Sayciinae (Chydoridae) of the World, SPB Academic Publishing, Amsterdam, 197 p.

Sousa F.D.R., 2012. Diversidade da fauna de Cladocera (Crustacea, Branchiopoda) associada à macrófitas em áreas úmidas naturais do Cerrado do Brasil Central. M.Sc. Thesis, University of Brasília.

Sousa F.D.R. and Elmoor-Loureiro L.M.A., 2008. Phytopilous cladocerans (Crustacea, Branchiopoda) of the Parque Nacional das Emas, State of Goiás. Biota Neotrop., 8, 159-166.

Thomaz S.M. and Cunha E.R., 2010. The role of macrophytes in habitat structuring in aquatic ecosystems: methods of measurement, causes and consequences on animal assemblages' composition and biodiversity. Acta Limnol. Bras., 22, 218-236.

Thomaz S.M., Dibble E.D., Evangelista L.R., Higuti J. and Bini L.M., 2008. Influence of aquatic macrophyte habitat complexity on invertebrate abundance and richness in tropical lagoons. Freshw. Biol., 53, 358-367.

Turki S. and Turki B., 2010. Copepoda and Branchiopoda from Tunisian temporary waters. Int. J. Biodivers. Conserv., 2, 86-97.

Van Damme K., Kotov A.A. and Dumont H.J., 2010. A checklist of names in Alona Baird 1843 (Crustacea: Cladocera: Chydoridae) and their current status: an analysis of the taxonomy of a lump genus. Zootaxa, 2330, 1-63.

Van Damme K., Sinev A.Y. and Dumont H.J., 2011. Separation of Anthalona gen.n. from Alona Baird, 1843 (Branchiopoda: Cladocera: Anomopoda): morphology and evolution of scraping stenothermic alonines. Zootaxa, 2875, 1-64.

van der Valk A.G., 2006. The Biology of Freshwater Wetlands, Oxford University Press, New York, 173 p.

Vieira L.C.G., Bini L.M., Velho L.F.M. and Mazão G.R., 2007. Influence of spatial complexity on the density and diversity of periphytic rotifers, microcrustaceans and testate amoebae. Fund. Appl. Limnol., 170/1, 77-85.

Williams V.L., Witkowski E.T.F. and Balkwill K., 2007. The use of incidence-based species richness estimators, species accumulation curves and similarity measures to appraise ethnobotanical inventories from South Africa. Biodivers. Conserv., 16, 2495-2513.

Zagmajster M., Culver D.C., Cristiman M.C. and Sket B., 2010. Evaluating the sampling bias in pattern of subterranean species richness: combining approaches. Biodivers. Conserv., 19, 3035-3048. 